19. Prestidge R.A. Ingestion and assimilation efficiency of Aeshna brevistyla and Hemicordulia australiae larvae (Odonata) // N.Z.J. Mar. and Freshwater Res., 1979, 13, № 1, 193-199.

20. Павлов С.И. Каннибализм как адекватная реакция животных на ухудшение условий обитания // Проблемы современной биологии: мат. VIII Международ. научно-практич. конференции (15.04.2013). М.: Спутник+, 2013. С. 51-56.

21. Определитель сельскохозяйственных вредителей по повреждениям культурных растений / Ред. Г.Е. Осмоловский. Л.: Колос - ЛО, 1976. 696 с.

22. Зайцев Ю.М., Медведев Л.Н. Личинки жуковлистоедов России. М.: ТНИ КМК, 2009. 246 с.
23. Scriber J.M., Slansky F.Jr. The nutritional ecology of immature insects // Annu. Rev. Entomol. Vol. 26/ Palo Alto. Calif., 1981, 183-211.

24. Бровдій В.М. Екологія і практичне значения жовтого вербового листоіда (Galerucella lineola F.) // Доповіні АН УРСР, 1968, Б, № 2. С. 176-179.

25. Мамедов А.А. Регуляция взаимоотношений в системе «фитофаг-кормовое растение» на примере хлопковой совки (Heliothis armigera $\mathrm{Hb}$.) и хлопчатника // Пищевая специализация насекомых (экологический, физиологический, эволюционный аспекты) / ред. С.Я. Резник. СПб.: Гидрометеоиздат, 1993. С. $93-$ 107.

\title{
TROPHIC BEHAVIOR STRATEGY OF PHYTOPHAGOUS INSECTS (AN EXAMPLE OF LEAF BEETLES COLEOPTERA, CHRYSOMELIDAE)
}

(C) 2016

S.I. Pavlov, candidate of biological sciences, associate professor of Biology, Ecology and Methods of Teaching Department Samara State University of Social Sciences and Education, Samara (Russia)

Abstract. The feeding behavior and feed spectra of the active life phases (imago and larvae) of 25 background species of leaf beetles (Coleoptera, Chrysomelidae) were studied in Samara region during 1974-2014. The analysis of trophic relationships members of these insects associated with about 400 species of higher (angiosperms) plants from 50 families and 2 classes is interesting not only in terms of their agricultural value, but also when considering bioecology issues (clarification of possible contacts of the organism with the environment). The strategy of the feeding behavior of phytophagous is a complex, which includes 20 episodes of behavioral responses, focuses on the search and acquisition of food and requires choosing the right direction of the influences. Food specialization provides (in order to avoid competition between types of consumers) the existence a rich assortment of food resources and different ways of their use (herbivore and detritivore, optional - food pollen and predation, cannibalism - only 8 types). There are two groups of plants consumed by phytophagous. They are basic (normally developing larvae and imago) and additional (used by imago in unfavorable periods) plants. The search for insect food consists of three types of reactions. They are distant (coarse and fine setting) and contact reactions. Agricultural importance of leaf beetles is determined by not only damage to plants, but also the action stimulating the productivity of phytocoenosis.

Keywords: leaf beetles; imago; larvae; Samara Region; strategy of trophic behavior; food specialization; herbivore; detritivore; optional food pollen; main fodder crops; residual fodder crops; search of food; distant orientation; contact orientation.

УДК 502.35

\section{ФЛОРИСТИЧЕСКИЕ И ГЕОБОТАНИЧЕСКИЕ ОСОБЕННОСТИ ПРОЦЕССА РЕНАТУРАЛИЗАЦИИ УСТЬ-СОКСКОГО КАРЬЕРА}

(C) 2016

Н.В. Прохорова, доктор биологических наук, профессор кафедры экологии, ботаники и охраны природы

Ю.В. Макарова, кандидат биологических наук, ассистент кафедры экологии, ботаники и охраны природы

Самарский наииональный исследовательский университет имени академика С.П. Королёва, Самара (Россия)

А.А. Головлёв, доктор географических наук, профессор кафедры мировой экономики

Самарский государственный экономический университет, Самара (Россия)

М.В. Самыкина, аспирант кафедры экологии, ботаники и охраны природы

А.М. Панкевич, студент биологического факультета

Самарский национальный исследовательский университет имени академика С.П. Королёва, Самара (Россия)

Аннотащия. Распространение открытого способа добычи нерудного сырья в Среднем Поволжье определяет актуальность исследований, посвященных искусственной рекультивации и естественной ренатурализации карьеров. В предлагаемой статье рассматриваются результаты флористического и геоботанического изучения Усть-Сокского карьера, в котором за последние 40 лет, прошедших после прекращения добычи карбонатного сырья, сформировалась вторичная растительность. В настоящее время самозарастающий Усть-Сокский карьер используется как естественный полигон для изучения вторичных антропогенных сукцессий, экологических, анатомо-морфологических, физиологических, биохимических и биогеохимических особенностей растений. В пределах карьера зафиксировано произрастание 107 видов сосудистых растений, принадлежащих к 83 родам, 35 семействам, 5 классам и 4 отделам. В составе локальной флоры карьера выявлено 6 краснокнижных видов Самарской области. Проникновение видов в карьер осуществляется семенным путем из окружающих его естественных фитоценозов Сокольих гор. Локальная флора карьера значительно беднее флоры Сокольих гор и от- 
Прохорова Н.В., Макарова Ю.В., Головлёв А.А., Самыкина М.В., Панкевич А.М. 03.02 .00 - общая биология Флористические и геоботанические особенности процесса ренатурализации...

личается от нее по видовому составу, что обусловлено спецификой абиотических условий, присущих техногенно нарушенной территории. Травянистые и древесные растения карьера характеризуются пониженным жизненным состоянием. Современная локальная флора карьера не сбалансирована, процесс ее формирования продолжается.

Ключевые слова: Сокольи горы; Усть-Сокский карьер; карбонатные породы; локальная флора; флористические спектры; фиторазнообразие; флористический и геоботанический анализ; ренатурализация; самозарастание; жизненные формы; экобиоморфный анализ; ценоморфы; трофоморфы; гигроморфы; гелиоморфы; антропогенная сукцессия.

Введение. В Российской Федерации распространен открытый способ добычи полезных ископаемых, что связано как с геологическими особенностями их залегания, так и с относительной дешевизной карьерной добычи [1;2]. Вместе с тем такой тип добычи минерального сырья отрицательно воздействует на природную среду. Как правило, после завершения промышленной разработки карьеры представляют собой деградированные (буквально оскальпированные) территории, лишенные почвенно-растительного покрова и являющиеся источниками поступления пыли в атмосферный воздух. Выведенные из эксплуатации карьеры служат фактором, активизирующим эрозионные процессы на прилегающих пространствах и снижающим природную и рекреационную привлекательность ландшафтов [3-5]. Указанные выше причины обусловливают необходимость восстановления техногенно нарушенных территорий, то есть их рекультивацию.

Однако рекультивация по ряду причин (прежде всего экономических) не всегда возможна, поэтому через какое-то время на нарушенных территориях начинается процесс естественного восстановления природной среды - ренатурализация. Как отмечает О.В. Исаенко [6, с. 81], естественный процесс самовосстановления природных комплексов начинается после прекращения или значительного уменьшения антропогенной нагрузки. В каждом конкретном случае процессы ренатурализации имеют локальные особенности, но для регионов, в которых они происходят, в характере этих процессов формируются общие черты и закономерности, которые должны учитываться в региональной практике рекультивации нарушенных ландшафтов. Данные обстоятельства обусловливают актуальность изучения процессов самозарастания карьерных разработок, выведенных из эксплуатации. Результаты подобных исследований углубляют и расширяют существующие представления о сукцессиях на техногенно нарушенных территориях. Они также могут использоваться для разработки технологий рекультивации нарушенных ландшафтов в конкретных условиях природной среды, повышая их эффективность и экономичность. Практическая значимость подобных исследований сочетается с возможностью изучения динамики вторичных сукцессий и получения фактических данных о механизмах устойчивости растений к изменившимся условиям среды обитания, и на этой основе - выявления наиболее устойчивых видов.

Территория Самарской области может служить удобным полигоном для исследования рекультивационных процессов в силу того, что карьерный способ добычи минерального сырья осуществлялся здесь с давних времен и активно практикуется в настоящее время. В качестве объекта исследований нами был выбран Усть-Сокский (Сокский, или Западный) карь- ep, расположенный в западной части Сокольих гор. В этом карьере на протяжении 50-70-х гг. XX в. осуществлялась промышленная добыча карбонатных пород для производства строительных материалов (щебня, строительных смесей и т.д.). В результате на северном макросклоне Сокольих гор, близ места впадения р. Сок в Саратовское водохранилище, образовалась крупная техногенная выемка максимальной протяженностью с севера на юг около 1 км и с запада на восток - около 2 км. Относительная высота отвесных бортов техногенного котлована достигает десятков метров, в отдельных случаях - 100-150 м [7]. Дно карьера, ограниченное скальными террасами, в целом ровное и плоское. С поверхности оно сложено плотными карбонатными породами, перемежающимися с выходами монолитного скального фундамента, и местами загромождено кучами крупных глыб некондиционных пород. После прекращения добычи минерального сырья рекультивационные работы на данной территории не производились. Таким образом, ориентировочно с 70-х гг. ХХ в. на территории УстьСокского карьера начался процесс естественного самозарастания - ренатурализации техногенно нарушенного ландшафта Сокольих гор.

Пространство, окружающее Усть-Сокский карьер, покрыто широколиственными лесами (на техногенно нарушенных участках - мелколиственными лесами и сосняками). Несмотря на то, что широколиственные леса в период функционирования карьера подверглись частичной вырубке (при прокладке грунтовых дорог и просек), в настоящее время их можно отнести к числу наименее нарушенных лесных массивов в пределах г.о. Самара. В связи с этим вполне оправдан сравнительный анализ флористических и геоботанических данных, полученных при исследовании УстьСокского карьера, с аналогичными данными, полученными при изучении лесного массива Сокольих гор, прилегающего к территории карьера.

Методика исследований. Исследования на территории Усть-Сокского карьера проводились маршрутным методом в весенний и летний периоды 2011 2014 гг. Маршруты пересекали все основные элементы техногенного рельефа карьера (днище, террасы, обвально-осыпные склоны). По результатам полевых и камеральных исследований был составлен список видов сосудистых растений и осуществлен таксономический, биоморфологический, фитоценотический и экологический анализ. При проведении анализа авторы руководствовались классификацией климаморф К. Раункиера [8], системой биоморф И.Г. Серебрякова и Т.И. Серебряковой [9-11], системой экоморф А.Л. Бельгарда [12] в модификации Н.М. Матвеева [13]. Номенклатура таксонов дана по сводке С.К. Черепанова [14].

В вегетационный период 2014 г. в Усть-Сокском карьере были произведены геоботанические исследо- 
вания, для чего на восточном, центральном и западном участках днища было заложено 5 пробных площадей (размером 10×25 м). Шестая (контрольная) пробная площадь была заложена вне карьера, на участке, примыкающем к его бровке с запада. Для учета состава и структуры травостоя на пробных площадях случайно-регулярным способом закладывалось по 10 учетных площадок $(1 \times 1$ м), на которых выявляли количество экземпляров, проективное покрытие (\%), фазу вегетации каждого вида травянистого растения. Таксационное изучение древостоя осуществлялось общепринятыми методами [15].

Результаты и их обсуждение. Проведенные исследования позволили выявить на территории УстьСокского карьера 107 видов сосудистых растений, принадлежащих к 83 родам, 35 семействам, 5 классам (Polypodiopsida, Equisetopsida, Pinopsida, Liliopsida, Magnoliopsida) и 4 отделам (Polypodiophyta, Equisetophyta, Pinophyta, Magnoliophyta). Класс Magnoliopsida является доминирующим в изучаемой локальной флоре: к нему относятся 27 семейств $(77,1 \%$ от общего числа семейств), 72 рода $(86,8 \%$ от общего числа родов) и 93 вида (86,9\% от суммы видов) [16]. Лидирующими по числу видов являются 11 семейств, которые содержат 78 видов, или $72,8 \%$ от их совокупности (табл. 1). Ведущими по количеству видов являются рода Salix (5 видов), Artemisia (4 вида), Populus, Hieracium и Epipactis (по 3 вида).

Сравнительный анализ флористических спектров Усть-Сокского карьера и западной части Сокольих гор (табл. 2) обнаруживает совпадение по положению первого (Asteraceae), второго (Rosaceae), третьего (Fabaceae) и пятого (Scrophulariaceae) доминирующих семейств, что свидетельствует о проникновении растений в карьер из сопредельных фитоценозов Сокольих гор. При сравнении флоры Усть-Сокского карьера с флорой Волго-Уральского региона отмечается совпадение лишь по положению первого (Asteraceae) и третьего (Fabaceae) семейств, что объясняется специфичностью абиотических условий в карьере.

Анализ жизненных форм растений по классификации И.Г. Серебрякова и Т.И. Серебряковой [9-11] выявил преобладание во флоре Усть-Сокского карьера травянистых поликарпиков (50 видов, или 46,7\% от их совокупности), среди которых выделяются группы короткокорневищных (18 видов, 16,8\%), длиннокорневищных (15 видов, 14,0\%), стержнекорневых (13 видов, $12,1 \%$ ), кистекорневых и клубнеобразующих (4 вида, $3,7 \%$ ) растений. Численность остальных биоморф убывает в ряду: деревья (15 видов, 14,0\%), однолетние травы (13 видов, 12,1\%), кустарники (10 видов, $9,3 \%)$, деревья или кустарники (8 видов, 7,5\%), двулетники (7 видов, 6,5\%), полукустарнички (2 вида, $1,9 \%)$, лианы (1 вид, 0,9\%). Господство короткокорневищных и длиннокорневищных многолетних трав, а также присутствие значительной доли древесных и полудревесных растений способствует (за счет ежегодного отмирания определенной части надземных и подземных органов) накоплению гумуса в корнеобитаемом слое субстрата и постепенному формированию почвенного покрова.

Согласно классификации жизненных форм К. Раункиера [8], в локальной флоре Усть-Сокского карьера доминируют гемикриптофиты (45 видов, или
42,0\%). Им существенно уступают фанерофиты (32 вида, 29,9\%), криптофиты (11 видов, 10,4\%) терофиты (10 видов, 9,3\%) и хамефиты (9 видов, 8,4\%). Совместно с криптофитами и терофитами, гемикриптофиты существенно повышают устойчивость растительного покрова карьера к перенесению неблагоприятных сезонно-климатических явлений.

Таблица 1 - Ведущие семейства в локальной флоре Усть-Сокского карьера

\begin{tabular}{|c|c|c|c|c|c|}
\hline \multirow{2}{*}{ № } & \multirow{2}{*}{ Семейство } & \multicolumn{2}{|c|}{ Число видов } & \multicolumn{2}{|c|}{ Число родов } \\
\hline & & абс. & $\%$ & абс. & $\%$ \\
\hline 1 & Asteraceae & 23 & 21,5 & 17 & 20,5 \\
\hline 2 & Rosaceae & 13 & 12,1 & 11 & 13,3 \\
\hline 3 & Fabaceae & 11 & 10,3 & 9 & 10,8 \\
\hline 4 & Salicaceae & 8 & 7,5 & 2 & 2,4 \\
\hline $5-6$ & Scrophulariaceae & 4 & 3,7 & 2 & 2,4 \\
\hline $5-6$ & Orchidaceae & 4 & 3,7 & 2 & 2,4 \\
\hline $\begin{array}{l}7- \\
11\end{array}$ & Poaceae & 3 & 2,8 & 3 & 3,6 \\
\hline $\begin{array}{l}7- \\
11\end{array}$ & Polygonaceae & 3 & 2,8 & 3 & 3,6 \\
\hline $\begin{array}{l}7- \\
11\end{array}$ & Brassicaceae & 3 & 2,8 & 3 & 3,6 \\
\hline $\begin{array}{l}7- \\
11\end{array}$ & Caprifoliaceae & 3 & 2,8 & 3 & 3,6 \\
\hline $\begin{array}{l}7- \\
11\end{array}$ & Grossulariaceae & 3 & 2,8 & 2 & 2,4 \\
\hline 4 & Всего: & 78 & 72,8 & 57 & 68,6 \\
\hline
\end{tabular}

Таблица 2 - Сравнительные флористические спектры

\begin{tabular}{|l|l|l|}
\hline \multicolumn{1}{|c|}{$\begin{array}{c}\text { Усть-Сокский } \\
\text { карьер }\end{array}$} & $\begin{array}{l}\text { Западная часть } \\
\text { Сокольих гор } \\
{[17]}\end{array}$ & $\begin{array}{c}\text { Волго- } \\
\text { Уральский } \\
\text { регион [18] }\end{array}$ \\
\hline Asteraceae & Asteraceae & Asteraceae \\
\hline Rosaceae & Rosaceae & Poaceae \\
\hline Fabaceae & Fabaceae & Fabaceae \\
\hline Salicaceae & $\begin{array}{l}\text { Brassicaceae }= \\
\text { Liliaceae }\end{array}$ & Brassicaceae \\
\hline $\begin{array}{l}\text { Scrophulariaceae } \\
\text { = Orchidaceae }\end{array}$ & $\begin{array}{l}\text { Scrophulariaceae } \\
\text { = Salicaceae }\end{array}$ & Cyperaceae \\
\hline
\end{tabular}

Экоморфный анализ локальной флоры УстьСокского карьера показал, что среди ценоморф преобладают сильванты (лесовики), биоценотический оптимум которых находится в биотопе климаксовых лесных сообществ. Лесовики и сорно-лесные растения насчитывают 46 видов, или 43,0\% от их общего количества. На втором месте по встречаемости стоят степанты (степняки) и сорно-степные виды (21 вид, $19,6 \%$ ), оптимальные условия для которых формируются, соответственно, в коренных степных сообществах и в биотопах изреженных (нарушенных) степных группировок, сухих и суховатых группировок пустырей. На третьем месте, незначительно уступая степным видам, находятся пратанты (луговики) и сорно-луговые виды (20 видов, 18,7\%) с биотическим оптимумом в биотопах ненарушенных естественных лугов и нарушенных луговых группировок. Самыми малочисленными оказываются рудеранты, или сорняки (10 видов, 9,3\%) и растения болотных сообществ палюданты (2 вида, 1,9\%). Результаты экоморфного анализа указывают на преимущественное проникно- 
Прохорова Н.В., Макарова Ю.В., Головлёв А.А., Самыкина М.В., Панкевич А.М.

вение видов из лесного массива Сокольих гор, окружающего Усть-Сокский карьер почти по всему его периметру. Наряду с лесным массивом Сокольих гор, источниками поступления видов в Усть-Сокский карьер могут служить лугово-степные и степные сообщества, сформированные на безлесном пространстве в окрестностях Столового склона, а также луговые и лугово-степные группировки лесных опушек. Нельзя исключать возможность попадания видов в карьер антропохорным способом.

Анализ трофоморфного состава локальной флоры Усть-Сокского карьера показывает, что основная масca сосудистых растений в карьере - мезотрофы $(56,4 \%)$ и мегатрофы (30,3\%). Олиготрофами являются только 13,0\% видов. Предполагая количественное преобладание во флоре карьера ультраолиготрофов и олиготрофов, видовые популяции которых процветают, соответственно, на обнаженных или перемещенных на дневную поверхность грунтах и бедных по содержанию гумуса и питательных элементов почвах, мы обнаружили доминирование видов, требующих среднебогатых и богатых питательными элементами почв. Можно полагать, что подобное соотношение трофоморф в составе флоры карьера не аномально, и в целом сходно с западной частью Сокольих гор, во флоре которых 62,5\% видов являются мезотрофами, $29,3 \%$ - мегатрофами и 8,2\% - олиготрофами [17].

В Усть-Сокском карьере преобладают мезофиты и ксеромезофиты (55 видов, 51,4\%). Встречаются мезогигрофиты, гигрофиты и ультрагигрофиты (20 видов, $18,7 \%)$. Такие виды нуждаются в гигротопах со средним и высоким уровнем влажности (от суховатых до мокрых). Такой уровень влажности обеспечивается, главным образом, за счет естественного водоема (небольшого озера) на днище карьера. В сухих и суховатых гигротопах успешно развиваются ксерофитные виды - мезоксерофиты и ксерофиты, на долю которых приходится 29,9\% от флоры Усть-Сокского карьера.

Наличие большого открытого и незаселенного пространства, а также лишенный почвенного покрова карбонатный субстрат способствуют проникновению и закреплению в карьере светолюбивых видов - гелиофитов (68 видов, 63,6\%) и выдерживающих незначительное затенение сциогелиофитов (27 видов, 25,2\%). Примесными видами следует считать гелиосциофиты (9 видов, 8,4\%) и сциофиты (3 вида, 2,8\%), оптимальные условия для существования которых складываются в полуплотнокронных лесах полутеневой структуры и в плотнокронных лесах теневой структуры.

На фоне невысокого уровня фиторазнообразия, во флоре Усть-Сокского карьера отмечено 6 видов сосудистых растений, внесенных в Красную книгу Самарской области [19]: хвощ ветвистый Equisetum ramosissimum Desf., дремлик тёмно-красный Epipactis atrorubens (Hoffm. ex Bernh.) Bess., д. широколистный E. helleborine (L.) Crantz, д. болотный E. palustris (L.) Crantz, тополь белый Populus alba L., боярышник волжский Crataegus volgensis Pojark. К числу редких и уязвимых таксонов Самарской области, нуждающихся в постоянном контроле и наблюдении, относятся ива остролистная Salix acutifolia Willd. и золототысячник красивый Centaurium pulchellum (Sw.) Druce. Кроме того, боярышник волжский является эндеми- ком средневолжской группы европейского типа ареала [20].

Анализ экобиоморфного состава локальной флоры Усть-Сокского карьера не дает полного представления о характере и особенностях процесса ренатурализации техногенно нарушенной территории. В этой связи на днище Усть-Сокского карьера и на прилегающей к нему территории было заложено шесть пробных геоботанических площадей. Днище - наиболее выровненная и менее динамичная по экологическим показателям часть карьера, в пределах которой выделяются участки с разным временным периодом самозарастания. Наиболее старая по времени выведения из эксплуатации часть днища карьера - восточная часть, средняя по времени выведения - центральная часть и наиболее молодая - западная часть. Пробная площадь 1 была заложена в восточной части, пробная площадь 2 - в центральной части около озера, пробные площади 3 и $3 \mathrm{a}-$ в центральной части напротив штолен, пробная площадь 4 - в западной части днища и контрольная пробная площадь 5 - на равнинном луговостепном участке, прилегающем с западной стороны к верхней террасе карьера.

На пробных геоботанических площадях было выявлено 28 видов травянистых и 7 видов древесных растений (табл. 3,4$)$. Наибольшее видовое разнообразие травянистых растений отмечается на пробной площади 5 (контроль), где встречается 14 видов из 14 родов и 10 семейств (Poaceae, Convallariaceae, Rosaceae, Geraniaceae, Polygalaceae, Apiaceae, Asclepiadaceae, Lamiaceae, Campanulaceae, Asteraceae) (табл. 3). Количество видов на каждой отдельно взятой пробной площади в карьере значительно меньше: 7 видов произрастает на пробной площади 3а, по 4 вида - на пробных площадях 2 и 3, по 3 вида - на пробных площадях 1 и 4. Доминирующими в карьере являются сем. Asteraceae и Poaceae: они насчитывают наибольшее число представителей (по 6 видов), которые встречаются на 5 из 6 пробных площадях. В целом на всех пробных площадях карьера произрастает 16 видов из 15 родов и 7 семейств (Equisetaceae, Poaceae, Juncaceae, Orchidaceae, Fabaceae, Scrophulariaceae, Asteraceae). Общими для карьера и контрольной площади являются 2 вида - ястребинка волосистая Hieracium pilosella L. и ковыль Лессинга Stipa lessingiana Trin. et Rupr.

Бедность видового состава травостоя УстьСокского карьера сопровождается его сильной изреженностью. Если на контрольной пробной площади 5 проективное покрытие достигает почти 85\%, то на днище карьера этот показатель варьирует от 3 до 33\%. Наиболее изреженный травянистый покров с проективным покрытием 3-9\% характерен для пробных площадей 1,3 и 4, расположенных в восточной и западной частях карьера (пр. пл. 1 и 4), а также в центральной его части напротив штолен (пр. пл. 3). На пробных площадях 2 и 3а проективное покрытие травянистого покрова составляет $22 \%$ и $33 \%$ соответственно. Самые низкие суммарные показатели проективного покрытия связаны, главным образом, с более глубоким залеганием грунтовых вод (пр. пл. 1, 3 и 4). Пробные площади 2 и 3а отличаются лучшими условиями увлажнения за счет пониженного рельефа (пр. пл. 3а) и расположения возле озера (пр. пл. 2). 
Влагообеспеченность площади 3а настолько высока, что там поселяются и демонстрируют высокие показатели жизненного состояния некоторые виды влаголюбивых растений, способные обитать на бедных питательными элементами субстратах - Equisetum hyemale L., E. ramosissimum Desf. и Epipactis palustris (L.) Crantz.

Отсутствие сформированного почвенного покрова, обедненность субстрата элементами минерального питания и жесткие условия инсоляции не позволяют на данном этапе процесса ренатурализации техногенного ландшафта Усть-Сокского карьера развиваться плотному и богатому видами травяному покрову. Об этом свидетельствует снижение показателей жизненного состояния трав на днище карьера по сравнению с контрольной пробной площадью.

Таблица 3 - Видовое разнообразие травянистых растений на изучаемых пробных площадях

\begin{tabular}{|c|c|c|c|c|c|c|c|}
\hline & Вид & $\begin{array}{c}\text { Пр. } \\
\text { пл. } \\
1\end{array}$ & $\begin{array}{c}\text { Пр. } \\
\text { пл. } \\
2\end{array}$ & $\begin{array}{l}\text { Пр. } \\
\text { пл. } \\
3 \mathrm{a}\end{array}$ & $\begin{array}{c}\text { Пр. } \\
\text { пл. } \\
3\end{array}$ & $\begin{array}{c}\text { Пр. } \\
\text { ПЛ. } \\
4\end{array}$ & $\begin{array}{c}\text { Пр. } \\
\text { пл. } \\
5\end{array}$ \\
\hline 1 & Artemisia campestris L. & & & & & & + \\
\hline 2 & Artemisia vulgaris L. & + & & & + & + & \\
\hline & $\begin{array}{l}\text { Bromopsis inermis } \\
\text { (Leyss.) Holub }\end{array}$ & & + & & & & \\
\hline 4 & $\begin{array}{l}\text { Calamagrostis epigeios } \\
\text { (L.) Roth }\end{array}$ & & + & + & & & \\
\hline 5 & Campanula sibirica $\mathrm{L}$ & & & & & & + \\
\hline 6 & Centaurea ruthenica Lam. & & & & & & + \\
\hline & $\begin{array}{l}\text { Elytrigia repens } \\
\text { (L.) Nevski }\end{array}$ & + & & & & & \\
\hline & $\begin{array}{l}\text { Epipactis palustris } \\
\text { (L.) Crantz }\end{array}$ & & & + & & & \\
\hline 9 & Equisetum hyemale L. & & & + & & & \\
\hline 10 & $\begin{array}{l}\text { Equisetum ramosissimum } \\
\text { Desf. }\end{array}$ & & & + & & & \\
\hline 11 & Euphrasia pectinata Ten. & & & + & & & \\
\hline 12 & Festuca valesiaca Gaudin & & & & & & + \\
\hline 13 & $\begin{array}{l}\text { Filipendula vulgaris } \\
\text { Moench }\end{array}$ & & & & & & + \\
\hline 14 & Geranium sanguineum L. & & & & & & + \\
\hline 15 & Hieracium pilosella L. & + & & & + & + & + \\
\hline 16 & Juncus compressus Jacq. & & + & & & & \\
\hline 17 & Jurinea ledebourii Bunge & & & & & & + \\
\hline 18 & Melampyrum arvense L. & & & + & & & \\
\hline 19 & Medicago lupulina L. & & & & + & & \\
\hline 20 & $\begin{array}{l}\text { Phleum phleoides } \\
\text { (L.) Karst. }\end{array}$ & & & & + & & \\
\hline 21 & $\begin{array}{l}\text { Poa stepposa } \\
\text { Kryl. (Roshev.) }\end{array}$ & & + & & & & \\
\hline 22 & Polygala vulgaris L. & & & & & & + \\
\hline 23 & $\begin{array}{l}\text { Polygonatum odoratum } \\
\text { (Mill.) Druce }\end{array}$ & & & & & & + \\
\hline 24 & Seseli libanotis (L.) Koch & & & & & & + \\
\hline 25 & $\begin{array}{l}\text { Stipa lessingiana } \\
\text { Trin. et Rupr. }\end{array}$ & & & & & + & + \\
\hline 26 & $\begin{array}{l}\text { Thymus zheguliensis } \\
\text { Klok. et Shost. p.p. }\end{array}$ & & & & & & + \\
\hline 27 & Tussilago farfara L. & & & + & & & \\
\hline 28 & $\begin{array}{l}\text { Vincetoxicum hirundinaria } \\
\text { Medik. }\end{array}$ & & & & & & + \\
\hline
\end{tabular}

Таблица 4 - Видовое разнообразие и численность древостоя на изучаемых пробных площадях

\begin{tabular}{|l|l|c|c|c|c|c|}
\hline & \multicolumn{1}{|c|}{ Вид } & $\begin{array}{c}\text { Пр. } \\
\text { пл. 1 }\end{array}$ & $\begin{array}{c}\text { Пр. } \\
\text { пл. 2 }\end{array}$ & $\begin{array}{c}\text { Пр. } \\
\text { Пл. 3 }\end{array}$ & $\begin{array}{c}\text { Пр. } \\
\text { пл. 4 }\end{array}$ & $\begin{array}{c}\text { Пл. 5 } \\
\text { Пл }\end{array}$ \\
\hline 1 & Acer platanoides L. & & & & & 2 \\
\hline 2 & Betula pendula Roth & 9 & & 1 & & 6 \\
\hline 3 & Pinus sylvestris L. & 10 & & 4 & 5 & 1 \\
\hline 4 & Populus nigra L. & 8 & 53 & 3 & 4 & \\
\hline 5 & Populus tremula L. & 5 & & & & \\
\hline 6 & Salix caprea L. & 1 & 14 & & & \\
\hline 7 & Quercus robur L. & & & & & 1 \\
\hline
\end{tabular}

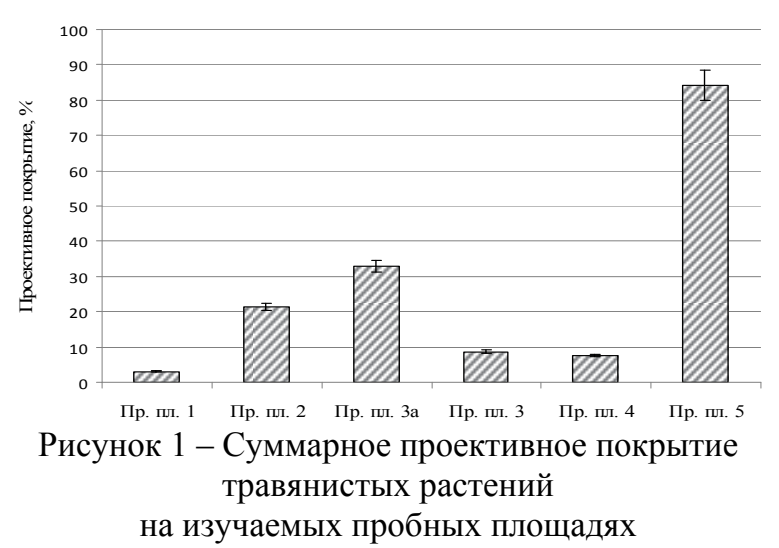

Видовой состав древесных растений так же, как и травянистых растений, не богатый (табл. 4). Древесные растения обитают преимущественно на днище карьера. Большинство из них принадлежит к сем. Salicaceae (Populus nigra L., P. tremula L., Salix caprea L.), но встречаются и представители сем. Pinaceae (Pinus sylvestris L.) и Betulaceae (Betula pendula Roth). Отличительной особенностью контрольной пробной площади 5 является отсутствие представителей сем. Salicaceae - их место занимают виды из сем. Aceraceae (Acer platanoides L.) и Fagaceae (Quercus robur L.).

Превалирование представителей сем. Salicaceae на типичных участках днища карьера может служить индикатором экологических условий. С одной стороны, они очень устойчивы к неблагоприятным климатическим условиям, светолюбивы, характеризуются быстрым ростом и высокой регенерационной способностью, с другой стороны - весьма требовательны к почвенному увлажнению и в естественных условиях произрастания часто проявляют себя как пойменные виды. Учитывая эти обстоятельства и тот факт, что заселение карьера древесными растениями осуществляется только семенным путем, можно сделать вывод о минимально достаточной влагообеспеченности поверхностных грунтов и горных пород карьера.

Поскольку в Усть-Сокском карьере древесные растения характеризуются тугорослостью, более мелкими и светлыми по сравнению с нормой листьями [7; 21], их современный габитус (форма и размеры кроны, порядок ветвления побегов, высота и толщина ствола) не позволяет достоверно судить о возрасте. Даже взрослые деревья (30-40 лет) отличаются низкорослостью, слаборазвитой кроной и относительно малым диаметром стволов в сравнении с нормой для данного вида. В ходе исследований в карьере к древостою относили только те экземпляры деревьев, диаметр ствола которых был равен или превышал 5 см. 
Прохорова Н.В., Макарова Ю.В., Головлёв А.А., Самыкина М.В., Панкевич А.М.

Именно поэтому в табл. 4 нет данных по пробной площади 3a, на которой произрастали Populus nigra L., Pinus sylvestris L. и представители рода Salix c толщиной ствола существенно меньше 5 см. В целом отметим, что для днища карьера характерны значительная изреженность древостоя и почти полное отсутствие участков с высокой сомкнутостью крон, наблюдаемой в сформированных лесных массивах.

Заключение. По состоянию на начало ноября 2015 г., в пределах Усть-Сокского карьера зафиксировано произрастание 107 видов сосудистых растений, принадлежащих к 83 родам, 35 семействам, 5 классам и 4 отделам. В составе флоры выявлено 6 краснокнижных видов Самарской области, 2 редких и уязвимых вида Самарской области и 1 эндемичный вид. Локальная флора карьера значительно беднее флоры Сокольих гор и отличается от нее по видовому составу, что связано со спецификой абиотических условий, присущих техногенно нарушенной территории. Тем не менее сходство флористических спектров УстьСокского карьера и прилегающей части Сокольих гор, а также результаты экобиоморфного анализа свидетельствуют о том, что проникновение видов в карьер в основном происходит из окружающего лесного массива.

При общности абиотических условий, на различных участках карьера эти условия существенно различаются - в первую очередь, по условиям увлажнения. Сформированная на сегодняшний день флора карьера не сбалансирована, процесс ее формирования не закончен и динамичен. Сделать заключение о том, какой может быть растительность карьера в будущем, пока не представляется возможным. Дальнейшее использование Усть-Сокского карьера как естественного полигона для изучения вторичных антропогенных сукцессий, экологических, анатомо-морфологических, физиологических, биохимических и биогеохимических особенностей растений позволит создать научную базу данных и сформировать ассортимент растений для рекультивации аналогичных техногенно нарушенных территорий.

\section{СПИСОК ЛИТЕРАТУРЫ:}

1. Славиковская Ю.О. Эколого-экономическая оценка способов разработки рудных месторождений в условиях перехода к устойчивому развитию // Горный информационно-аналитический бюллетень. 2004. № 11. C. $122-124$.

2. Максимова Е.Ю., Абакумов Е.В. Особенности почвообразования на карбонатных субстратах в посттехногенных экосистемах северной тайги и лесостепи // Известия Самарского научного центра РАН. 2011. T. 13, № 5. C. 42-47.

3. Платонов А.П., Платонов В.А. Основы общей и инженерной экологии. Ростов-на-Дону: Феникс, 2002. $352 \mathrm{c}$.

4. Мотузова Г.В., Безуглова О.С. Экологический мониторинг почв. М.: Гаудеамус, 2007. 237 с.

5. Арустамов Э.А., Левакова И.В., Баркалова Н.В. Экологические основы природопользования. М.: Издательско-торговая корпорация «Дашков и Кํ), 2008. $320 \mathrm{c}$.

6. Исаенко О.В. Эколого-географический анализ процесса ренатурализации ландшафтов Крымского предгорья (в связи с использованием территории под застройку) // Строительство и техногенная безопасность. 2013. Вып. 46. С. 80-85.

7. Головлёва Н.М., Головлёв А.А., Прохорова Н.В. Усть-Сокский карьер: эстетический, научно-познавательный и природоохранный аспекты // Заповедное дело России: принципы, проблемы, приоритеты: матер. Междунар. науч. конф. Т. 1. Бахилова Поляна, 2003. C. 159-162.

8. Raunkiaer C. The life forms of plants and statistical plant geography. Oxford, 1934. 47 p.

9. Серебряков И.Г. Экологическая морфология растений: жизненные формы покрытосеменных и хвойных. М.: Высшая школа, 1962. 378 с.

10. Серебряков И.Г. Жизненные формы высших растений и их изучение // Полевая геоботаника. 1964. T. 3. C. 146-205.

11. Серебрякова Т.И. Учение о жизненных формах растений на современном этапе // Итоги науки и техники. Сер. Ботаника. 1972. Т. 1. С. 84-169.

12. Бельгард А.Л. К вопросу об экологическом анализе и структуре фитоценозов в степи // Вопросы биологической диагностики лесных биогеоценозов Присамарья. Днепропетровск: Изд-во Днепропетр. гос. ун-та, 1980. С. 11-42.

13. Матвеев Н.М. Основы степного лесоведения профессора А.Л. Бельгарда и их современная интерпретация. Самара: Самарский университет, 2012. $128 \mathrm{c}$.

14. Черепанов С.К. Сосудистые растения России и сопредельных государств (в пределах бывшего СССР). СПб.: Мир и семья - 95, 1995. 992 с.

15. Матвеев Н.М. Биоэкологический анализ флоры и растительности (на примере лесостепной и степной зоны): учеб. пособие. Самара: Изд-во «Самарский университет», 2006. $311 \mathrm{c.}$

16. Самыкина М.В. К особенностям формирующейся флоры Усть-Сокского карьера (Самарская область) // Экологический сборник 5: Труды молодых ученых Поволжья. Тольятти: ИЭВБ РАН, Кассандра, 2015. C. 326-330.

17. Макарова Ю.В., Прохорова Н.В., Головлёв А.А. Материалы к флоре западной части Сокольих гор (Самарская область) // Фиторазнообразие Восточной Европы. 2013. Т. VII, № 1. С. 28-46.

18. Иванова А.В. Таксономическая характеристика флоры Самарской Луки // Известия Самарского научного центра РАН. 2010. Т. 12. № 1. С. 31-41.

19. Красная книга Самарской области. В 2 т. Т. 1. Редкие виды растений, лишайников и грибов / под ред. Г.С. Розенберга, С.В. Саксонова. Тольятти: ИЭВБ PAH, 2007. $372 \mathrm{c}$.

20. Плаксина Т.И. Самарская Лука - феномен природы Среднего Поволжья // Вестник Самарского государственного университета. 1999. № 2 (12). С. 158171.

21. Макарова Ю.В., Куликова М.В., Прохорова Н.В., Головлёв А.А. Особенности естественного лесовосстановления в карбонатных карьерах Самарской области // Лесостепь Восточной Европы: структура, динамика и охрана: сборник статей Междунар. науч. конф., посв. 140-летию И.И. Спрыгина. Пенза: Изд-во ПГУ, 2013. С. 175-177. 


\section{FLORISTIC AND GEOBOTANIC FEATURES OF THE RENATURALIZATION PROCESS OF UST'-SOKSKIY QUARRY}

(C) 2016

N.V. Prokhorova, doctor of biological sciences, professor of Ecology, Botany and Nature Protection Department

Yu.V. Makarova, candidate of biological sciences, assistant of Ecology, Botany and Nature Protection Department Samara National Research University, Samara (Russia)

A.A. Golovlyov, doctor of geographical sciences, professor of World Economy Department Samara State University of Economics, Samara (Russia)

M.V. Samykina, postgraduate student of Ecology, Botany and Nature Protection Department

A.M. Pankevich, student of Biology Faculty

Samara National Research University, Samara (Russia)

Abstract. Studies devoted to artificial reclamation and natural renaturalization of the open cuts are important because of the distribution of the nonmetallic open-cut mining in the Middle Volga. The following article contains the results of floristic and geobotanical study of the Ust'-Sokskiy quarry, where the secondary plantation has been forming for the last 40 years after calciferous stock mining and quarrying. At present overgrowing Ust'-Sokskiy quarry is used as a natural testing field for exploration of the secondary anthropogenic successions, ecological, anatomical, morphological, physiological, biochemical and biogeochemical peculiarities of plants. 107 species of the vascular plants belonging to 83 genera, 35 families, 5 classes and 4 phyla were fixed in the quarry. 6 species from the Red Book of Samara Region were found in the composition of the local flora. Species penetration to the quarry is realized by dissemination from the nearest natural phytocenoses of Sokolii Mountains. Local flora of the quarry is significantly poorer than that of the Sokolii Mountains and differed by species composition that is explained by abiotic conditions specifics which are inherent to the technologically disturbed territory. Herbaceous and woody plants of the quarry are characterized by depressed vital condition. Modern local flora of the quarry is unbalanced and the process of its forming is continued.

Keywords: Sokolii Mountains; Ust'-Sokskiy quarry; calciferous rocks; local flora; floristic specters; phytodiversity; floristic and geobotanical analysis; renaturalization; overgrowth; life forms; ecobiomorphic analysis; coenomorphs; trophomorphs; hygromorphs; heliomorphs; anthropogenic succession.

УДК $502.4(470.43)$

\section{ЭКОЛОГО-ТУРИСТИЧЕСКИЙ ПОТЕНЦИАЛ САМАРСКОЙ ОБЛАСТИ: РЕСУРСЫ РАСТИТЕЛЬНОГО МИРА}

(C) 2016

С.В. Саксонов, доктор биологических наук, профессор,

заведующий лабораторией проблем фиторазнообразия, заместитель директора по научной работе

А.Г. Розенберг, кандидат биологических наук, младший научный сотрудник группы экономики природопользования

С.А. Сенатор, кандидат биологических наук, старший научный сотрудник лаборатории проблем фиторазнообразия

Институт экологии Волжского бассейна РАН, Тольятти (Россия)

И.В. Казанцев, кандидат биологических наук, декан естественно-географического факультета, доцент кафедры химии, географии и методики их преподавания

Самарский государственный социально-педагогический университет, Самара (Россия)

B.М. Васюков, кандидат биологических наук, научный сотрудник лаборатории проблем фиторазнообразия Институт экологии Волжсккого бассейна РАН, Тольятти (Россия)

Аннотация. В статье рассматривается развитие экологического туризма, которое, прежде всего, базируется на посещении привлекательных и уникальных объектов. В полной мере этим требованиям соответствует растительный мир. Впервые сформулировано 10 оснований, стимулирующих развитие познавательного экологического туризма (видовое разнообразие, реликтовые виды; эндемичные виды; виды, описанные с территории региона впервые для науки; растения, признанные охраняемыми и занесенные в Красную книгу; растительные сообщества, уникальные по происхождению и составу; зональные, типичные растительные сообщества; места концентрации растений на территории памятников природы; особо ценные природные территории федерального уровня охраны; ключевые ботанические территории) и 5 оснований, стимулирующих развитие событийного экологического туризма (даты рождения исследователей; даты проведения экспедиций; даты организации центров по изучению растительного мира; даты публикации важнейших ботанических сочинений; даты проведения крупнейших научных форумов). Описывается концентрация памятников природы и распределение особо охраняемых природных территорий в пределах Самарской области. В статье используется обобщенный критерий оценки фитосозологического статуса данных территорий. Отмечается, что Самарская область является перспективной территорией для развития внутреннего туризма, где важная и определяющая роль принадлежит экологическому туризму.

Ключевые слова: особо охраняемые природные территории; памятники природы; экологический туризм; познавательный туризм; событийный туризм; видовое разнообразие; растительные сообщества; растительный мир; реликты; эндемики; редкие растения; Красная книга; Самарская область. 